\title{
RESENSI BUKU \\ TEACHING AND RESEARCHING SPEAKING \\ (Rebecca Hughes, 2002. London: Pearson Education, xii + 196 pp)
}

oleh Suwarna

FBS Universitas Negeri Yogyakarta

\section{A. Rangkuman}

Secara garis besar bukti Teaching And Researching Speaking (Pengajaran dan Penelitian Berbicara) tulisan Rebecca Hughes terdiri dari tiga bagian yaitu I: konsep, II: isu, problem, dan sajian awal paradigma dalam pengajaran dan penelitian berbicara, dan III: penelitian berbicara.

Pada bagian pertama atau awal Hughes berusaha mendeskripsikan konsep berbicara sebagai keterampilan berbahasa. Sebagai keterampilan berbahasa, berbicara bukanlah keterampilan yang dapat dipisahkan secara deskrit. Ia berinterjeksi dan berkolaborasi dengan kemampuan lain. Kemampuan yang berinterjeksi dan berkolaborasi dengan keterampilan berbicara adalah kemampuan linguistik kewacanaan, leksikon, gramatika, dan fonologi seperti tampak pada bagan 1 .

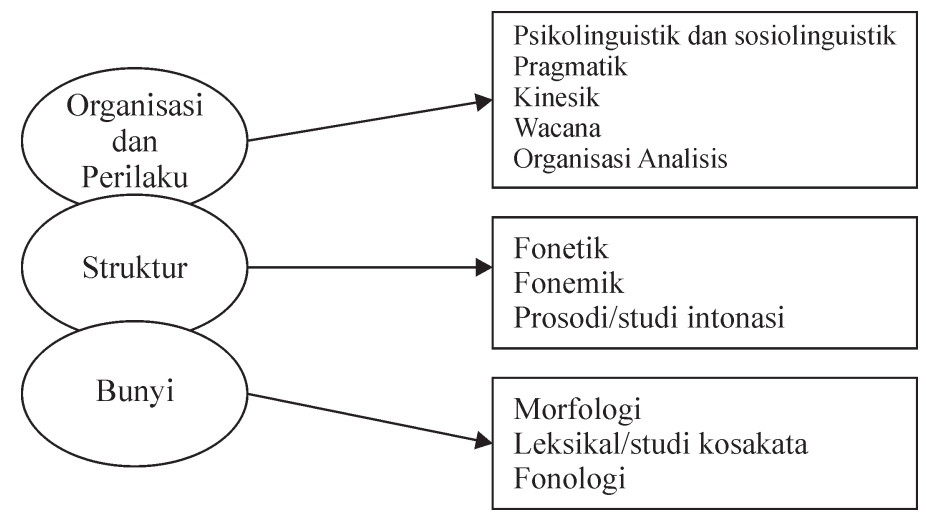

Bagan 1.

Tingkat dan bidang penelitian yang termasuk dalam tuturan dan percakapan 
Hughes juga menunjukkan hubungan antara berbicara dengan menulis. Keduanya sebagai dua kemampuan aktif produktif. Sebagai keterampilan aktif, berbicara menuntut pembicara untuk memfungsikan organ-organ pendukung berbahasa (dari syaraf hingga organ berbicara). Sebagai keterampilan produktif, pembicara dituntut menghasilkan bahasa verbal lisan. Keterampilan menulis juga keterampilan aktif dan produktif Akan tetapi, bedanya adalah produksi yang dihasilkan oleh pembicara adalah bahasa verbal lisan (tuturan), sedangkan produksi yang dihasilkan oleh penulis adalah bahasa verbal tulisan.

Hubungan berbicara dan menulis itu diperluas dalam bentuk wacana, yaitu wacana berbicara dan wacana tulis. Keduanya memiliki aspek produksi dan aspek sosial dengan karakteristik masing-masing aspek berbeda. Secara produktif wacana tergantung pada konteks. Tuturan lisan dapat disampaikan secara spontan tanpa direncanakan. Karena tidak terencana dan diliputi oleh konteks, sering terjadi deviasi dan eliminasi struktur. Akan tetapi masih dapat dipahami karena konteks. Tuturan ini bersifat sementara (momental). Artinya selesai tuturan diluncurkan, hilang dari pendengaran, tidak dapat diamati lagi, kecuali suara itu direkam. Wacana lisan bersifat oral (disampaikan melalui organ berbicara) dan dinamis (mudah berubah, terdapat deviasi dan eliminasi struktur dan leksikon), seperti pemyataan seorang pembeli bakmi, "Saya goreng, kakak saya godok!". Secara semantik gramatika kalimat itu tidak berterima, tetapi secara semantik kontekstual kalimat tersebut dapat berterima.

Sebaliknya secara produktif wacana tulis tidak tergantung pada konteks. Penulis dapat menuangkan idenya mana saja dan kapan saja, mengenai topik apa saja tidak dibatasi ruang dan waktu. Wacana tulis direncanakan oleh penulis. Wacana tulis bersifat visual, dapat diamati berkali-kali, dan bersifat statis (tidak berubah).

Secara sosial wacana lisan mudah berubah karena konteks. Wacana ini bersifat interpersonal yaitu ada hubungan langsung antara pembicara dan mitra bicara. Wacana lisan secara sosial bersifat informal, santai, dan tidak kaku (luwes). Namun, ada juga wacana lisan yang 
bersifat formal (pidato resmi). Itulah sebabnya wacana lisan bersifat retoris (informal dan formal). Wacana lisan bersifat primer (asli), masih lengkap antara fonem segmental dan suprasegmental.

Sementara itu secara sosial wacana tulis, bersifat tetap, dapat diamati berkali-kali. Kontrakstual adalah berdasarkan kontrak. Artinya berdasarkan kesepakatan diri penulis sendiri atau dengan mitra tulis. Wacana tulis bersifat formal diatur dengan gramatika, relatif sedikit/ jarang terjadi deviasi dan elinasi. Jika ini terjadi dapat mengurangi keterbacaan dan keberterimaan secara maknawi. Wacana tulis bersifat prestisius. Secara prestis orang yang dapat menyampaikan wacana tulis dengan bagus menunjukkan status (prestis) penulis. Dengan kata lain tulisan merupakan cermin prestise penulis. Apabila wacana lisan bersifat primer, wacana tulis bersifat sekunder. Sekunder adalah bersifat turunan, yaitu turunan dari wacana lisan ke wacana tulis. Tabel 1 sebagai ringkasan perbedaan aspek produksi dan sosial pada wacana lisan dan wacana tulis.

Tabel 1. Aspek wacana

\begin{tabular}{|c|l|l|l|}
\hline No. & \multicolumn{1}{|c|}{ Wacana } & \multicolumn{1}{|c|}{ Aspek Produksi } & \multicolumn{1}{|c|}{ Aspek Sosial } \\
\hline 1. & Wacana lisan & 1. tergantung pada & 1. berubah \\
& & konteks, & 2. interpersonal \\
& & 2. tidak terencana, & 3. informal \\
& & 3. sementara & 4. stigmatisasi \\
& & 4. oral, & 5. retorik \\
& & 5. dinamis & 6. primer \\
\hline 2. & Wacana tulis & 1. dekontekstuali- & 1. tetap \\
& & sasi & 2. kontrakstual \\
& & 2. terencana, & 3. formal \\
& & 3. tidak sementara, & 4. prestisius \\
& & 4. visual, & 5. logik \\
& & 5. statis & 6. sekunder \\
\hline
\end{tabular}


Bagian kedua atau tengah buku ini menyajikan informasi paling banyak terkait dengan isu dan problem dalam pengajaran dan penelitian berbicara. Isu-isu antara lain isu kemampuan berbahasa dengan kemampuan berbicara, hubungan antara keduanya, isu kemampun berinteraksi secara lisan, isu kondisi yang diciptakan oleh penguji (tester) ketika melakukan tes berbicara agar kondisi itu mirip dengan kondisi autentik, isu tentang uji berbicara dalam berbagai bentuk dan genre, tes berbicara secara diskret maupun secara integrasi. Tes secara diskret adalah alat tes tunggal untuk menguji (mengevaluasi) kemampuan berbicara. Tes integratif adalah penggunaan beberapa jenis tes untuk mengevaluasi kemampuan berbicara. Hughes juga menyajikan tiga kriteria tes berbicara. Ketiga dalam bahasa Inggris yaitu IELTS (International English Language Testing System), CPE (Certificate of Proficiency in English), CELS (Certificates in English Language Skills).

Dari isu-isu itu, Hughes mengangkat berbagai problem berbicara. Problem ini terkait dengan pendekatan, materi, pengajaran, dan problemproblem ekspresi berbicara itu sendiri. Problem-problem ini tidak berdiri sendiri tetapi terkait dengan aspek-aspek gramatika dan kemampuan ajaran. Problem berbicara bukan hanya disebabkan oleh ketidakmampuan kebahasaan (gramatika bahasa/usage), tetapi juga penggunaan bahasa itu sendiri (use the language) atau anak-anak yang mengalami disfungsi berbicara.

Dan isu dan problem tentang pendekatan, pengajaran, materi, dan ekspresi berbicara, Hughes mulai mengajukan paradigma penelitian berbicara. Pada bagian ini, Hughes mengembangkan beberapa rekomendasi baru. Rekomendasi ini bertujuan (1) memberikan beberapa isu-isu kunci tentang teori dalam penelitian berbicara, (2) mengkaji beberapa perkembangan yang signifikan di dalam penelitian proses berbahasa, dan (3) menghubungkan antara berbicara, memori, proses berbahasa, dalam konteks pengajaran bahasa yang lebih luas.

Deskripsi untuk mencapai tujuan tersebut, Hughes menguraikan orientasi secara teoritis tentang peran dan status berbicara. Secara teoritis, ternyata bentuk-bentuk tulisan dapat mempengaruhi berbicara. 
Implikasi pernyataan ini, misalnya terjadi pada pidato resmi, pengajaran, orasi ilmiah, dsb. Sebelum berbicara, pada umumnya mereka (pelaku berbicara) membuat tulisan terlebih dahulu. Dalam proses komunikasi lisan ini, Hughes juga menyatakan ada hubungan antara ujaran, memori, dan proses pembangkitan pesan hingga ekspresi lisan.

Untuk mendukung pernyataannya itu, Hughes menunjukkan buktibukti secara patologis antara lain hubungan dan peran pikiran, berbicara, dan tulisan. Pikiran berpengaruh dalam memproses ekspresi, baik lisan maupun tulisan. Ekspresi lisan berupa performansi pengejaan (secara lisan). Dalam ekspresi ini ada pembicara atau penulis yang lebih baik daripada yang lain. Ini menunjukkan bahwa pembicara/ penulis yang satu memiliki kemampuan dalam olah pikir dan mentransfer pesan ke dalam ekspresi lisan atau tulisan. Pernyatan Hughes juga didukung oleh Pound, Croisilie, Weinrich, Miceli dan Capasso, dsb. Hughes memprediksikan bahwa penelitian hubungan antara pikiran dan ekspresi dapat menjadi topik penelitian selanjutnya. Hasil penelitian itu dapat dijadikan bahan mengajarkan berbicara, menulis, dan strategi pengajarannya.

Pada bagian ketiga atau akhir Hughes mulai membuka uraian tentang penelitian berbicara. Uraian bagian III, Hughes cenderung memulai uraian tentang penelitian berbicara dengan objek kelas. Hal ini didasarkan atas pertimbangan bahwa (1) kelas sebagai somber terjadinya berbicara, bahkan Hughes yakin bahwa penelitian tentang wacana lisan lebih potensial (dan variatif) daripada wacana tulis; wacana tulis sebagai turunan (traskripsi) wacana lisan. Sebagai turunan, wacana tulis tidak selengkap atau seutuh wacana lisan. Dalam wacana tulis ada aspek yang ditinggalkan yaitu aspek prosodi atau fonem suprasegmental; (2) dalam kelas terjadi wacana lisan. Wacana lisan ini bukan hanya berasal darn guru, siswa, tetapi juga dialog interaktif antara guru dan siswa; (3) guru dapat memulai penelitian wacana lisan dalam kelasnya sendiri. Guru dapat meneliti wacananya sendiri ataupun wacana siswa, atau dialog yang terjadi dalam pengajaran di kelas. Penelitian juga dapat dilakukan oleh peneliti murni (profesi sebagai peneliti saja seperti para peneliti dari Balai Bahasa). Artinya pelaku penelitian, memang seorang peneliti, bukan guru. 
Menurut Hughes agar peneliti dapat dimanfaatkan secara maksimal perlu kerjasama antara peneliti, guru atau pemakai hasil penelitian, dan publikator. Peneliti murni melakukan:

(1) mencari problem-problem spesifik dari guru,

(2) menunjukkan penting penelitian terhadap siswa,

(3) memastikan hasil kerja yang dapat diterapkan,

(4) meneliti guru dan pengembang materi.

Guru sebagai pemakai hasil penelitian:

(1) menanggapi atau mengakses ide-ide baru yang bermanfaat

(2) memanfaatkan solusi-solusi problem (misalnya problem berbicara, problem gramatika dalam berbicara)

(3) menggunakan dan menyesuaikan pemakaian tes (yang telah teruji/diteliti)

(4) memberikan balikan secara jujur

(5) menggunakan ide-ide Baru untuk menggali topik penelitian.

Publikator sebagai fasilitator:

(1) memberikan layanan hasil penelitian secara on line

(2) menjadi jembatan antara peneliti dan pengembang materi pengajaran

(3) menemukan tim peneliti berdasarkan permintaan guru.

Untuk mendukung kajian dan uraiannya, Hughes memberikan solusi (1) berbagai jenis penelitian, (2) sumber-somber penelitian berbicara dan (3) memberikan jalan awal penelitian dengan memanfaatkan teknologi informasi komputer.

Berbagai jenis penelitian yang diajukan oleh Hughes adalah analisis wacana, pendekatan eksperimen dalam berbicara, penelitian tindakan, analisis percakapan, dan penelitian dengan pendekatan kualitatif dan kuantitatif.

Selain kelas, sumber-sumber penelitian antara lain berbicara dan etnografi atau studi lintas budaya, etnografi komunikasi, 


\section{3}

etnografi berbicara, berbicara dan psikolinguistik, berbicara dan studi neorolinguistik, berbicara dan korpus linguistik, organ berbicara, organisasi dan masyarakat, pengenalan ujaran dan dan teks ke berbicara, serta berbicara dan teknologi baru. Pemanfaatan teknologi informasi dengan komputer untuk penelitian berbicara antara lain arsip suara dan database (on line dan CD-ROM), lafal dan intonasi berbicara melalui teknologi komputer.

\section{B. Pembahasan}

Rebecca Hughes melalui bukunya dengan tiga bagian pokok I: konsep, II: isu, problem, dan paradigma dalam pengajaran berbicara, dan III: penelitian berbicara telah menunjukkan keruntutan cara berpikir. Keruntutan itu ditunjukan dengan tahapan pendahuluan berupa eksplorasi tentang berbagai isu dan problema berbicara. Berdasarkan isu dan problema, Hughes mencoba memaparkan paradigma penelitian berbicara. Paradigma itu diaplikasikan dalam berbagai bentuk penelitian seperti analisis wacana, pendekatan eksperimen dalam berbicara, penelitian tindakan, analisis percakapan, dan penelitian dengan pendekatan kualitatif dan kuantitatif.

Dilihat dari isinya, secara proporsional buku ini masih didominasi oleh pengajaran berbicara yang terkait dengan isu dan permasalahan penelitian berbicara. Hal ini wajar, sesuai dengan bukunya yang berjudul Pengajaran dan Penelitian Berbicara. Hughes lebih cenderung menguraikan pengajaran untuk menghantarkan uraian tentang penelitian berbicara. Hughes tidak berbicara tentang bagaimana seharusnya pengajaran berbicara, tetapi lebih condong pada pengajaran berbicara yang dapat digunakan sebagai objek penelitian. Kita tidak akan menemukan pendekatan, metode, strategi, dan evaluasi pengajaran berbicara dalam buku tersebut. Akan tetapi berbagai isu dan problem yang terkait dengan penelitian berbicara.

Uraian seperti tersebut menunjukkan bahwa pengajaran berbicara merupakan salah satu sumber penelitian berbicara. Kelas sebagai sumber berbicara oleh Joyce dan Weil (1996) dikatakan pengajaran sebagai

DIKSI Vol.12, No.2, Juli 2005 
inquiri. Kelas sebagai inquiri (penyelidikan atau penelitian) karena di dalamnya terjadi proses komunikasi yang kompleks, dari unsur segmental (bahasa) dan suprasegmental (prosodi), konteks, pelaku wicara, strategi komunikasi, strategi pengajaran, dsb. Agar terjadi proses komunikasi diperlukan strategi komunikasi. Strategi komunikasi ini Clark dan Clark (Pringgawidagda, 2002) menguraikan strategi komunikasi terdiri dari perencanaan strategi, program artikulator, atau program motorik (performansi berbicara) dan ditambahkan oleh Chesterfield dan Chesterfield (Pringgawidagda, 2002), strategi koreksi, tipologi strategi komunikasi (strategi kognitif, metakognitif, reduksi, berprestasi, pragmatik komunikasi), dapat juga strategi pembelajaran (dalam berbicara) dari karakteritik, alasan pemakaian, konteks berbicara, refleksi berbicara, membantu meningkatkan keterampilan berbicara (Clouston, 1997), strategi yang efektif dalam pembelajaran, berbicara guru (teacher talk), gilir berbicara (turn talking) masalah retorika, public speaking, dan seni berbicara (Beebe \& Beebe, 1991, Lucas, 1989), efektivitas strategi yang digunakan guru untuk membantu kesempurnaan berbicara menuju (kemiripan) penutur asli http://www.teachnology.Comitutorials/teaching/ els/.), penutur berbicara ragam panggung yang disebut etnopuitika (Kadarisman, 2001).

Penelitian mengenai berbicara belum banyak dilakukan atau tidak sebanyak penelitian di luar berbicara. Hal ini disebabkan penelitian berbicara tidak mudah, terutama penelitian yang berkaitan dengan unsur suprasegmental. Penelitian ini tidak produktif, tidak banyak peneliti mengkaji unsur suprasegmental, misalnya intonasi, tempo, dinamik, jeda, tekanan, pemanjangan, irama. Ada beberapa penelitian tentang intonasi, tetapi itu sudah terlalu lama, yaitu penelitian yang dilakukan pada zaman penjajahan dan pasca kemerdekaan Indonesia seperti penelitian William Marsden, Tassilo Adam dan James P Butle, Hans Kahler, J. Vergun, Sutan Takdir Alisjahbana, Armijn Pane dan Fokker. Penelitian yang relatif "baru" yaitu penelitian Amran Halim (1984) "Intonasi dalam Hubungganya dengan Sintaksis Bahasa Indonesia". Penelitian ini merupakan disertasi Amran Halim di Universitas Michigan. 
Penelitian terkait dengan unsur suprasegmental lainnya sangat tidak produktif. Oleh karena itu, gagasan Hughes tentang penelitian berbicara ini perlu disambut dengan baik. Namun, implikasinya diharap tidak hanya terbatas pada penelitian yang terkait dengan unsur segmental, unsur suprasegmental juga perlu mendapatkan perhatian oleh para peneliti.

Mengkaji masalah berbicara sebagai keterampilan berbahasa, tidak akan lepas dari unsur-unsur kebahasaan dan keterampilan berbahasa lainnya. Unsur kebahasaan atau gramatika (usage) mendasari kompetensi kebahasaan seseorang. Sedangkan penggunaan bahasa (berbahasa/use the language) merupakan performansi (penampilan berbahasa). Performansi merupakan "jelmaan" kompetensi (Chomsky, 1965). Kemampuan individu untuk memanfaatkan kompetensi dalam performansi komunikatif oleh Savignon (1986) disebut kompetensi komunikatif. Kompetensi komunikatif ini terdiri dan kompetensi gramatika, sosiolinguistik, strategi, dan wacana. Dalam berbicara seseorang memerlukan kompetensi komunikatif. Gramatika bahasa mendasari aturan bahasa. Sosiolinguistik mendasari bagaimana harus berbahasa. Strategi merupakan cara atau teknik agar komunikasi (lisan) dapat berlangsung atau terhenti, dengan atau tidak menyinggung perasaan, dsb. Kompetensi wacana mendasari seseorang agar dapat berbicara secara utuh, komprehensif, dan koheren.

Dalam hal kedeskritan keterampilan berbicara, saya setuju dengan Hughes bahwa keterampilan berbahasa bukanlah keterampilan yang dapat dideskritkan, terlepas dengan unsur-unsur lain. Unsur-unsur itu antara lain tercakup dalam kompetensi komunikatif yang diajukan oleh Savignon. Akan tetapi, sebagai bahan kajian atau objek penelitian keterampilan berbicara harus dipisahkan dari keterampilan lainnya karena dalam sebuah penelitian, fokus penelitian harus jelas.

Di sisi lain, Hughes menghubungkan antara keterampilan berbicara dengan menulis karena kedua memiliki persamaan dan perbedaan, ditinjau dari aspek produksi dan aspek sosial (Hughes, 2002:10-11). Berbicara dan menulis bersifat aktif produktif. Hughes tidak menyinggung keterampilan lain yang bersifat aktif reseptif yaitu menyimak dan membaca. Alangkah 
lebih, komprehensif apabila Hughes juga menyinggung keterampilan yang aktif reseptif ini sebab is menyatakan bahwa berbicara tidak dapat dipisahkan secara deskrit. Rupanya Hughes terjebak pada kompetensi kebahasaan, dan "mengabaikan" hubungan antar keterampilan berbahasa secara pragmatik. Kita perlu menyadari bahwa keterampilan berbicara ditunjang oleh keterampilan menyimak dan membaca. Seseorang dapat berbicara karena diawali dengan menyimak. Keterampilan berbicara semakin diperkaya dengan menyimak kehidupan sehari-hari dan membaca berbagai referensi dan fenomena. Pembicara yang baik, umumnya juga seorang penyimak yang baik. Keterampilan berbicara juga ditunjang oleh kemampuan membaca. Pembicara yang baik dia juga seorang pembaca yang baik karena materi wicara yang dimiliki merupakan hasil membaca. Namun, sebaliknya belum tentu pembicara yang adalah seorang penulis yang baik. Banyak bukti menunjukkan orang yang pandai pidato, tetapi tidak pintar menulis. Ada juga orang pandai menulis, tetapi tidak pandai berbicara di muka umum.

Sekali lagi berbicara sebagai keterampilan sulit dipisahkan dengan unsur linguistik dan nonlinguitik atau keterampilan berbahasa lainnya. Namun, sebagai bahan kajian, berbicara merupakan keterampilan yang dapat dipilahkan. Dengan kata lain, secara pragmatis, keterampilan berbicara tidak dapat berdiri sendiri (terikat dan terkiat dengan unsur lain). Akan tetapi, berbicara dapat dikaji secara deskrit sebagai bahan kajian penelitian. dibuktikan sendiri oleh Hughes pada bagian uraian penelitian. Hughes secara terpisah membuat paradigm penelitian berbicara, menunjukkan berbagai jenis penelitian yang dapat digunakan untuk meneliti berbicara, sumber-sumber penelitian berbicara, bahkan memanfaatkan teknologi informasi. Hal ini menunjukkan bahwa penelitian berbicara dapat dikaji secara terfokus, "lepas" dari unsur iainnya.

Terkait dengan paradigma dan pemanfaatan teknologi informasi, saya mengatakan bahwa Hughes baru memberikan kunci-kuncinya saja. Hughes masih berbicara pada taraf permukaan (kulit) belum sampai pada taraf aplikasi. Namun ini sungguh bermanfaat. Hughes telah. membuka 
dan menunjukkan jalan menuju ke penelitian berbicara. Ia sebagai pembuka dan penunjuk jalan, tetapi ia sendiri tidak ikut menyusuri. Biarlah orang lain yang menyusuri pengajaran dan penelitian berbicara. Terlebih jika dilihat pada usaha Hughes dalam menunjukkan para pembaca untuk mernberdayakan teknologi informasi (komputer dengan segala pengembangannya). Pemanfaatan teknologi informasi yang disampaikan oleh Hughes juga baru pada tingkat awal. Hal itu boleh dikatakan sebagai pendahuluan atau penunjukkan, bahwa penelitian selain memanfaatkan sumber-sumber pustaka tradisional (dokumen, buku, atau referensi), peneliti juga dapat menggunakan teknologi informasi (internet) sebagai tempat berburu data dan referensi. Secara rinci Hughes menunjukkan web-site yang dapat diakses lengkap dengan pokok permasalahan yang diperlukan oleh peneliti berbicara. Oleh karena itu, setelah pembaca membaca buku Hughes yang berjudul Pengajaran dan Penelitian Berbicara, saya sarankan untuk memperdalam referensi metodologi penelitian dan aplikasi penelitian dalam teknologi komputer.

Kekuatan atau kelebihan buku Teaching and Researching Speaking setidalawa ada lima berikut ini:

1. Sajian uraian sistematis dan hirarkhis. Artinya uraian disajikan secara runtut dari tingkat yang mendasari menuju tingkat yang lebih tinggi. Uraian dimulai dari pengajaran berbicara, isu dan problem pengajaran berbicara, paradigma penelitian, hingga pemanfaatan teknologi komputer.

2. Setiap pembahasan suatu topik atau pokok bahasan tertentu, Hughes selalu memberikan ilustrasi dan merujuk pada ahlinya.

3. Ilustrasi dan rujukan itu ditulis dan disajikan secara ringkas dengan tampilan khusus sehingga pembaca lebih mudah membaca, merujuk, atau mencari hal-hal yang penting.

4. Kutipan yang lebih penting atau mendapatkan perhatian lebih khusus dengan disajikan dalam kotak sehingga menarik pembaca. Performansi kutipan ini oleh penulis dapat menjadi ilustrasi. Bagi pembaca performansi kutipan yang disajikan Hughes dapat menjadi ajang rekreasi dalam membaca, menandai bagian yang substansi, dan 
mudah untuk dikenali. Dua langkah yang dilakukan oleh Hughes (memberikan kutipan dan disajikan dalam kotak) untuk menunjukkan kepada pembaca agar memberikan perhatian kepada hal yang penting itu.

5. Pada setiap awal bab diberikan tujuan pembahasan. Dengan demikian pembaca lebih mudah memprediksi isi uraian dan mengambil pokok uraian, dan menyimpan dalam retensi ingatan.

Hal-hal yang masih perlu ditingkatkan dapat disarankan berikut ini:

1. Uraian cenderung masih dalam tingkat dasar. Oleh karena itu, masih perlu pendalaman terutama dalam tingkat aplikasi.

2. Pada sajian pemakaian teknologi komputer, Hughes baru menunjukkan referensi-referensi tentang berbicara yang dapat diakses melalui internet. Ini perlu disadari bahwa di negara penulis, internet sudah merupakan hal yang biasa sehari-hari. Padahal buku Hughes dibaca di mana-mana (seluruh dunia). Hughes kurang menyadari bahwa teknologi internet di negara lain belum seperti di negaranya. Sajian rekomendasi penggunaan teknologi komputer dalam bukunya belum dapat dipahami atau dilaksanakan secara utuh oleh pembaca di negaranegara berkembang. Oleh karena itu, lebih memadai apabila Hughes menyajikan contoh aplikasi teknologi komputer dalam pengajaran dan penelitian berbicara, tidak sekedar menunjukkan referensi dalam Internet. Namun, barangkali Hughes memiliki pemikiran lain. Jika ditunjukkan contohnya, pembaca cenderung tidak kreatif karena hanya mencontoh yang sudah ada.

\section{Penutup}

Penelitian tentang berbicara belum banyak dilakukan oleh para peneliti. Oleh karena itu, terbitnya buku Teaching dan Reseaching Speaking oleh Hughes (2002) diharap dapat memacu dan memicu minat peneliti dalam penelitian berbicara, khusus kajian fonem atau unsur suprasegmental. Orang berbicara bukan hanya manifestasi unsur 
segmental, tetapi juga unsur segmental yang dominan dalam penentuan makna secara kontekstual. Penelitian unsur suprasegmental memang tidak mudah. Itulah sebabnya hingga kini penelitian ini kurang/tidak produktif. Walaupun tidak mudah, bukan berarti penelitian unsur suprasegmental sulit (tidak dapat) dilakukan. Semua itu tergantung tekad dan kemampuan para peneliti. Oleh karena itu, terbitnya buku Hughes ini semoga menjadi motivasi dan tonggak bangkitnya penelitian berbicara khususnya penelitian untuk unsur suprasegmental (intonasi, jeda, tekanan, pemanjangan, tempo, dinamik, atau irama, dsb.).

\section{DAFTAR PUSTAKA}

Beebe, Steven A \& Beebe, Susan J. 1991. Pubic Speaking. New Jersey. Prentice Hall.

Clouston, Michael Lessard. 1997. Language Learning Strategies: An Overview for L2 Teachers. http://iteslj.org/Articles/LessardCluoston-Strategy.html.

Chomsky, Noam. 1965. Aspect of The Theory of Syntax. Cambridge: Cambridge University Press.

Fluency. Dalam Effective Strategies for Language Teaching English Language Leaners. http://www.teachnology.Com/tutorials/ teaching/els/.

Halim, Amran. 1984. Intonasi dalam Hubungannya dengan Sintaksis Bahasa Indonesia.

Hughes, Rebecca. 2002. Teaching and Researching Speaking. London: Pearson Education.

Joyce, Bruce \& Weil, Marsha. 1996. Models of Teaching. Boston: Allyn and Bacon.

Kadarisman, Effendy. 2001. Berkenalan dengan Etnopuitika. Makalah Seminar Nasional. Jakarta: UI.

Pringgawidagda, Suwama. 2002. Strategi Penguasaan Berbahasa. Yogyakarta: Adicita.

DIKSI Vol.12, No.2, Juli 2005 
Savignon, Sandra. 1983. Communicative Competence: Theory and Classroom Practice. Massachusetts: Addison Wesley Publishing.

The Role Metacognition in Second Language Teaching and Learning. http://www.ericdigests.org./2003-1/role.htm 